\title{
Development of Accountability Scale for Quality Education in Nigerian Secondary Schools
}

\author{
S. O. Bandele \\ Department Of Guidance And Counselling \\ Faculty Of Education, Ekiti State University, Ado-Ekiti \\ E-Mail:sambandele@grail.com, Phone No:08139152995 \\ S. A. Ajayi
Department Of Guidance And Counselling,
Faculty Of Education, Ekiti State University, Ado-Ekiti
E-Mail:adisayemi@yahoo.com, Phone No: 08062336147
}

\section{Doi:10.5901/mjss.2013.v4n3p695}

\section{Abstract}

This study was on the development of accountability scale for quality education in Nigerian Secondary Schools. The work involved Construction and Validation of the accountability scale to measure variables such as quality of output, discipline, provision of infrastructure, resource utilization and human development in Nigerian Schools. The construction and the validation of the scale passed through three (3) stages and the number of samples used for the Stage 1, Stage 2 and the Final stage were 1,000, 300 and 1,500 respondents comprising students, teachers, parents, professionals, community members and secondary school administrators in the Public Secondary School, Inspectorate and Quality Assurance Divisions in the Ministry of Education. The characteristics of the final version of the scale were within the limit of acceptable validity and reliability coefficients of accountability scale. The scale has correlation coefficient of 0.420 validity which was established by Kerlinger (1979) convergent construct approach; and reliability established by Split-Half and Cronbach's Alfa with 0.874 and 0.933 correlation coefficient.

\section{Introduction}

Educational accountability attempts to measure variables which enhance quality of Education (Stechers and Hanser 1992). Secondary education is packaged in Nigeria to make students acquire knowledge, skills and moral education that will make them productive and efficient in the society. The researcher noted that every stakeholder of secondary education is designed to be active and be fully involved in achieving these objectives.

Igbuzor (2006) asserted that secondary education is a right to be given to children after their primary education and this is in line with the UNESCO declaration of education for all (EFA) by 2015. This declaration was also in agreement with the Federal Government of Nigeria vision of 2020 which involved making education like other sectors viable in the nation attaining an emergent economy.

Federal Ministry of Education (FME) in Nigeria (2009) aspired for investments in the secondary education to be functional, economical, political, social and pragmatic for the national growth and development. Secondary education with clear sense of direction and shared commitment by all the stakeholders under the Chairmanship of Schools' Principals and the Chairperson of School Board Management Committee (SBMC).

Accountability scale for quality education at the secondary school level hoped to address the superfluous, uncoordinated and commonly use phrases of quality assurance and quality of education which had posed problems in secondary education matters in Nigeria.

Bandele (2007) noted that every stakeholder of secondary education should lbe accountable for his actions and inactions and that holistic measures should be applied while evaluating the (SWOT) Strength, Weakness, Opportunities and Threats Analysis of Secondary Education.

The Development of Accountability Scale for Quality Education in Nigerian Secondary Schools (ASSQEN) is unique in the sense that it accounts for what and who are accountable for quality education in spite of many studies that have been carried out on accountability. ASQEN is divided into 2 major parts. Part A is on the Bio-data and Part B is 
divided into four sections. Section "A" consists of Students' Accountability, Section "B" consists of Teachers Accountability, Section " $C$ " is on Parents and Community Members Accountability and Section " $D$ " is on Administrators' Accountability for Quality in Secondary Schools Education.

The ASQEN being a locally developed instrument was acceptable to the custom, environment and educational background of Secondary Schools in Nigeria. It is also capable of measuring accountability indices of secondary schools in Nigeria.

\section{Purpose of the Study}

The study consists of the development of accountability scale for quality education in Nigerian Secondary Schools with the following objectives:

1. Measure the accountability indices of quality education at the secondary schools level in Nigeria.

2. Measure who and what is accountable for quality education in Nigerian Secondary Schools.

3. Measure the psychometric properties of the scale.

Procedure: The development of Accountability Scale for Quality Education in Nigerian Secondary Schools (ASQEN) was the collection and compilation of 300 items from the students, teachers, schools administrators in the public secondary schools and the Ministry of Education, Area Education Offices, parents/community members, professionals, researcher and colleagues.

The items were studied, improved and upon and were subsequently given to experts in Tests and Measurement and Education Foundation and Management to ensure suitability and quality of the scale. It then passed through standard construction procedures and was adjudged to be good, valid and reliable to measure quality of education in Nigerian Secondary Schools. The entire 300 items were then trial tested and refined for setting of norms and practical research applications.

\subsection{Stage I}

The field trial testing consisted of 1,000 respondents comprising 500 students, 300 teachers, 150 parents and community members and 50 Education Officials. The researcher and the research assistants were involved in the administration of the scale. The sample was taken through stratification and simple random sampling techniques in urban and rural areas in 10 public secondary schools and 5 towns where the schools were located. Secondary education officials were selected in Inspectorate and Quality Assurance Units in the Ministry of Education, Local Education Areas of Ekiti State, Nigeria. The responses of the respondents to Field Trial I were subjected to statistical analysis using Pearson Product Moment Correlation method for computing inter-item homogeneity of items at $r \leq 0.05$ with $r \geq 0.3000$ significant value to obtain the 100 item which formed the second version of the scale.

\subsection{Stage 2}

The 100 item scale was administered on 300 respondents comprising 150 students, 100 teachers and schools administrators, 30 parents and community members and 20 Education Officials selected from five public secondary schools. The schools were located in urban and rural areas; the sample included the Area Education Officers and Ministry of Education officials in Ekiti State of Nigeria. This Field Trial II gave further opportunity of restructuring the scale to 50 items through Pearson Moment Correlation method for computing inter-item homogeneity of items at $r \leq 0.05$ with $r \geq 0.3000$ significant values.

\section{Main Study}

The sample of the main study was 1,500 comprising 720 students, 480 teachers, 180 parents/community members and 120 Secondary Education Officials selected in 3 states in the South Western zone namely Ekiti, Lagos and Ondo States of Nigeria. The sample was selected by purposive, stratified and simple random sampling techniques in the public secondary schools and towns located in the rural and urban areas, and Area Education Offices and Units handling Secondary Education matters in the Ministries of Education. The three stages gave three versions as shown in Table I. 
Table I: Versions of ASQEN

\begin{tabular}{|c|c|c|c|}
\hline Versions & No of Items & $\%$ of $1^{\text {st }}$ Version & $\%$ of $2^{\text {nd }}$ Version \\
\hline First & 300 & 100 & \\
\hline Second & 100 & 33.33 & 100 \\
\hline Final & 50 & 16.67 & 50 \\
\hline
\end{tabular}

The 300 items represented one hundred (100\%) percent. The 100 items represented thirty three point thirty three (33.33\%) percent of the 300 items, while the 50 items represented sixteen point sixty seven (16.67) percent of the 300 items.

\section{Hypothesis One}

The instrument will not have high validity coefficient when administered Nigerian Secondary Schools

The instrument was validated using Kerlinger Convergent Approach with the correlation of the scores of ASQEN and Quality Assurance Questionnaire (QAQ) with a sample of 35 respondents, the result obtained is presented in

Table 2: Validity of ASQEN

\begin{tabular}{|c|c|}
\hline Instruments & r-calculated \\
\hline ASQEN/QAO & 0.420 \\
\hline
\end{tabular}

Table 2 shows correlation coefficient of 0.420 at 0.05 level of significance. It reveals that the scale is valid and useful to measure accountability variables for quality education in Nigerian Secondary Schools.

\section{Hypothesis Two}

The instrument will not have significant reliability coefficient when administered in Nigerian Secondary Schools.

Table 3: Showing the Reliability of ASQEN

\begin{tabular}{|c|c|c|}
\hline Subjects & No of Subjects & r-calculated \\
\hline Teachers & 40 & 0.802 \\
\hline Students & 40 & 0.721 \\
\hline Cronbach's Alpha & 50 items & 0.933 \\
\hline Split-Half & 50 items & .874 \\
\hline
\end{tabular}

$\mathrm{R} \leq 0.05$

The test-retest reliability of the scale showed 0.802 and 0.721 correlation coefficient at 0.05 level of significance when it was administered among 40 teachers and 40 students within the time lag of two (2) weeks. The Split-Half and Cronbach's Alpha Internal consistency are 0.874 and 0.933 correlation coefficients at 0.05 significant values. It revealed that the scale is reliable, consistent and usable for measuring accountability indices for quality education in Nigerian Secondary Schools.

Table 4 showing the Pearson Correlation Coefficients of ASQEN items at 0.01 level of significance.

Accountability scale for quality education in Nigerian secondary schools

Table 4 (a). Students accountability for quality education in secondary schools

\begin{tabular}{|c|l|c|}
\hline S/N & \multicolumn{1}{|c|}{ Items } & r-value \\
\hline 1 & Schools are becoming less strict on student disciplinary matter &. $\mathbf{2 9 5 ^ { * * }}$ \\
\hline 2 & Educational opportunities such as scholarships, awards, should be made available in schools &. $\mathbf{4 6 8 ^ { * * }}$ \\
\hline 3 & Students supplement personal studies with what they are taught in schools &. $\mathbf{2 1 4 ^ { * * }}$ \\
\hline 4 & Traffic congestions could make students to be late to schools &. $\mathbf{2 5 5 ^ { * * }}$ \\
\hline 5 & Relevant committees in schools should preserve the societal values &. $\mathbf{4 2 4 ^ { * * }}$ \\
\hline
\end{tabular}




\begin{tabular}{|c|l|c|}
\hline 6 & Students are to be guided towards attainment of their educational goals in life &. $\mathbf{4 7 7 ^ { * * }}$ \\
\hline 7 & The school environment are attractive to learning & $.150^{* *}$ \\
\hline 8 & Students lack essential materials for teaching-learning & $.367^{* *}$ \\
\hline 9 & Languages committee should inculcate into the students clear communication skills &. $\mathbf{4 7 5}$ \\
\hline 10 & Teachers are adequate for the teaching of subjects in schools & $.144^{* *}$ \\
\hline 11 & Reports should be made to school authorities about lazy teachers &. $\mathbf{4 2 1 ^ { * * }}$ \\
\hline 12 & Examination results should be released on time to students &. $\mathbf{5 0 5}$ \\
\hline 13 & Learning in schools should be made easy through teaching aids & $.511^{\text {** }}$ \\
\hline
\end{tabular}

Table 4 (b). Teachers accountability for quality education in secondary schools

\begin{tabular}{|c|c|c|}
\hline $\mathrm{S} / \mathrm{N}$ & Items & r-value \\
\hline 14 & Teachers should be sensitive to exploit educational opportunities for their students & $.522^{\star \star}$ \\
\hline 15 & Teachers should strengthen students in their areas of weaknesses & $.522^{\star *}$ \\
\hline 16 & 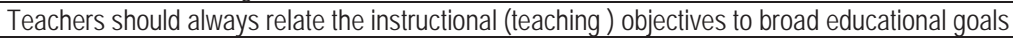 & $.524^{* \star}$ \\
\hline 17 & Clubs activities should be tailored toward all round development of students & $.480^{* *}$ \\
\hline 18 & $\begin{array}{l}\text { Teachers should encourage regular visit by parents to schools for the inspection of their } \\
\text { children/wards academic work }\end{array}$ & $.470^{* *}$ \\
\hline 19 & $\begin{array}{l}\text { Teachers should encourage the parents to buy essential books, materials needed by their } \\
\text { children from time to time }\end{array}$ & $.586^{* *}$ \\
\hline 20 & Teachers should encourage objective peer ratings of their students from time to time & $.498^{\star *}$ \\
\hline 21 & Teachers should inculcate moral education into their students & $.591^{* *}$ \\
\hline 22 & Teachers should encourage their students to be hard working in their studies & $.562^{* *}$ \\
\hline 23 & Teachers should encourage students to maintain school and personal cleanliness & $.611^{* *}$ \\
\hline 24 & Teachers should encourage students in the leadership and democratic roles & $.559^{\star \star}$ \\
\hline 25 & Teachers should make referral cases of students problems to schools counsellors promptly & $.567^{* \star}$ \\
\hline 26 & Living at distant places can affect the teachers getting to school to time & $.407^{* *}$ \\
\hline
\end{tabular}

Table 4 (c). Parents and communities accountability

\begin{tabular}{|c|c|c|}
\hline S/N & Items & r-value \\
\hline 27 & Committees system should be well funded in schools for the achievement of their set goals & $.512^{* *}$ \\
\hline 28 & $\begin{array}{l}\text { Parents and communities should assist in teachers and students regularity to schools through } \\
\text { holding of meetings with the schools' management }\end{array}$ & $.549^{* *}$ \\
\hline 29 & $\begin{array}{l}\text { Parents and communities should assist the schools' administration in exploiting opportunities in } \\
\text { schools. }\end{array}$ & $.565^{\star *}$ \\
\hline 30 & $\begin{array}{l}\text { Parents and communities should assist schools, teachers and students' in solving confronting } \\
\text { problems. }\end{array}$ & .589** \\
\hline 31 & Parents and communities should agitate for prompt release of examination results to students & $.538^{\star *}$ \\
\hline 32 & $\begin{array}{l}\text { Parents and communities should agitate for prompt release of examination results to students } \\
\text {. }\end{array}$ & $.451^{* *}$ \\
\hline 33 & $\begin{array}{l}\text { Hard work by all and sundry in secondary education could lead to the finding of solutions to } \\
\text { students mass failure }\end{array}$ & $.469^{* *}$ \\
\hline 34 & $\begin{array}{l}\text { Parents and communities should assist schools in providing teachers to supplement } \\
\text { government provisions in areas of shortages }\end{array}$ & $.498^{* *}$ \\
\hline 35 & Prizes and awards are to be given to outstanding students and teachers in schools & $.538^{\star *}$ \\
\hline 36 & Parents and communities should be kept abreast of educational policies & $.510^{* *}$ \\
\hline 37 & School committees should be given recognition by the schools' management. & $.564^{* *}$ \\
\hline 38 & Parents and communities should be interested in achieving secondary educational policies & $.554^{\star *}$ \\
\hline
\end{tabular}

Table 4 (d). School administrators accountability for quality education in secondary schools

\begin{tabular}{|c|l|c|}
\hline S/N & \multicolumn{1}{|c|}{ Items } & r-values \\
\hline 39 & School administrators should be able to translate their schools to admirable heights &. $\mathbf{5 6 6 ^ { * * }}$ \\
\hline 40 & They should create and sustain the sense of hard work in teachers and students &. $\mathbf{5 9 1 ^ { * * }}$ \\
\hline 41 & They should ensure that teachers keep schools records properly and adequately. &. $\mathbf{6 4 5 ^ { * * }}$ \\
\hline 42 & $\begin{array}{l}\text { School administrators should ensure that students are fully prepared for exams through } \\
\text { adequate teaching and coaching. }\end{array}$ & $\mathbf{. 6 2 1 ^ { * * }}$ \\
\hline
\end{tabular}




\begin{tabular}{|c|l|c|}
\hline 43 & $\begin{array}{l}\text { They should handle carefully all the reports to the Teaching Service Commission and the } \\
\text { Ministry of Education }\end{array}$ & $.623^{* *}$ \\
\hline 44 & $\begin{array}{l}\text { Leadership trainings, Seminars and Workshops should be made accessible to school } \\
\text { administrators }\end{array}$ & $.597^{* *}$ \\
\hline 45 & School administrator-s should have good sense of assigning duties to members of staff & $.606^{* *}$ \\
\hline 46 & School administrators should consider staff's potentials in delegating authority & $.569^{* *}$ \\
\hline 47 & $\begin{array}{l}\text { School administrators should operate in harmony with every member of staff to uplift the schools' } \\
\text { academic standard }\end{array}$ & $.578^{* *}$ \\
\hline 48 & They should have listening ears and attend to the needs of students and teachers promptly & $.603^{* *}$ \\
\hline 49 & They should be caring to both staffers and the students & $.52^{* *}$ \\
\hline 50 & School administrators should make teaching profession attractive to others & $.540^{* *}$ \\
\hline
\end{tabular}

The 50 items of ASQEN is significant and capable of measuring accountability indices for quality education in Nigerian secondary schools.

\section{Conclusion and Recommendation}

The scale was adjudged to be good, valid and reliable. It is capable of measuring accountability indices in Nigerian Secondary Schools and perhaps the world at large. The scale can be used conveniently in the urban and rural secondary schools for accountability measures. The scale is not gender bias among the teachers, schools' administrators, parents and community members. It can be used among the people of various religions.

\section{References}

Alonge, M.F. (2004) Measurement and Psychology (2nd edition) Ado-Ekiti: Adebayo Printing Nigeria Limited.

Anastasi, A. (1982): Psychological Testing New York: Macmillan Co.

Anastasi, A. (1982): Psychological Testing, New York: Macmillan Co.

Artley, W. (2001) The Performance Based Management Handbook. California Training Resources and Data Exchange.

Ayodele, J.B. (2005): Fundamentals of Systems Analysis in Education, Ikeja Lagos: Bolabay Publishing Consultants.

Bandele S.O. (2004). Educational Research in Perspective, Ibadan: Niyi Printing Venture.

Bandele S.O. (2007). The Journal of the Association of National Accountant of Nigeria, Yaba Lagos, Tee Prints.

Bloom, B, (1956). Taxonomy of Educational Objectives. The Classification of Educational Goals, New York Longmans Green and Co.

Bregman, J \& Bryner, K (2003) Quality of Secondary Education in Africa SEIA Publication of (ADEA) Association for the Development of Education in Africa.

Cronbach, I. \& Algina A. (1971). Test Validation in R.L. Thondike (ed) Educational Measurement, 2nd edition. Washington D.C. 443 507 American Council on Education.

Cronbach, L.J. (1988) Five Perspectives on Validity Argument in Testing Erlbaum Hillside, N.J. Publication.

Dumas, J.S. (1999). A Practical Guide to Usability Testing Intellect, Portland, Online Publication.

Gillbert, L.S. (2006). Developing a Teacher assessment Instrument Validation and Implications. Atlanta:University of Georgia Publication Hopinks, D \& Stanley, C. (1981). Educational and Psychological Measurement and Evaluation 6th Edition New Jersy Prentice-Hall, Inc. Eaglewood Clifts.

Igbuzor O. (200). Civil Society Action Coalition on Education for All Ofoe Igbuzor atoctional.org.

Stecher, L.M. \& Hanser, L.M. (1992) Local Accountability in Vocational Education: A Theoretical model and its Limitation, New York: Online Pulication 
